\section{Sighting record of Bengal Florican Houbaropsis bengalensis (Gmelin, 1789) (Aves: Gruiformes: Otididae) in Lower Dibang Valley District, Arunachal Pradesh, India}

\author{
Alolika Sinha ${ }^{1}$, Jillol Hoque ${ }^{2}$, Tilak Pradhan ${ }^{3}$, \\ Manish Kumar Bakshi ${ }^{4}$, Jibi Pulu ${ }^{5}$, Alok Kumar \\ Singh $^{6} \&$ M. Firoz Ahmed ${ }^{7}$ \\ 1,2,3,4,7 Aaranyak, 50 Evergreen, Samanway Path, Beltola Survey, \\ Guwahati, Assam 781028, India \\ ${ }^{5}$ Mishmi Hill Camp, Ezengo, Roing, Lower Dibang Valley \\ District, Arunachal Pradesh 792110, India \\ ${ }^{6}$ Ranger, Dibang Forest Division, Arunachal Forest Department \\ Lower Dibnag Valley District, Arunachal Pradesh, India \\ Email: ${ }^{1}$ alolika@aaranyak.org (corresponding author), \\ ${ }^{4}$ manishkoolbakshi@gmail.com, ${ }^{5}$ mishmihillcamp@gmail.com, \\ ${ }^{7}$ firoz@aaranyak.org
}

The Bengal Florican Houbaropsis bengalensis (Gmelin, 1789) is a Critically Endangered species inhabiting the Indian subcontinent and Southeast Asia (BirdLife International 2012). It is a ground nesting grassland bird (Poudyal et al. 2008), which was once common in northern India, Nepal and the Brahmaputra Valley of Assam (Rahmani 2001) in northeastern

Date of publication (online): 26 November 2012

Date of publication (print): 26 November 2012

ISSN 0974-7907 (online) | 0974-7893 (print)

Editor: Rajiv S. Kalsi

Manuscript details:

Ms \# 02831

Received 10 June 2011

Final received 03 October 2012

Finally accepted 15 October 2012

Citation: Sinha, A., J. Hoque, T. Pradhan, M.K. Bakshi, J. Pulu, A.K. Singh \& M.F. Ahmed (2012). Sighting record of Bengal Florican Houbaropsis bengalensis (Gmelin, 1789) (Aves: Gruiformes: Otididae) in Lower Dibang Valley District, Arunachal Pradesh, India. Journal of Threatened Taxa 4(14): 3375-3376.

Copyright: (c) Alolika Sinha, Jillol Hoque, Tilak Pradhan, Manish Kuma Bakshi, Jibi Pulu, Alok Kumar Singh \& M. Firoz Ahmed 2012. Creative Commons Attribution 3.0 Unported License. JoTT allows unrestricted use of this article in any medium for non-profit purposes, reproduction and distribution by providing adequate credit to the authors and the source of publication

Acknowledgements: The authors are thankful to all the volunteers from the local community, without their help and cooperation the field work would not have been possible. We acknowledge the constant support from the Arunachal Forest Department.

urn:Isid:zoobank.org:pub:1AA009A7-E5D7-42AA-96CE-725761AED769

\section{OPEN ACCESS | FREE DOWNLOAD}

India. Bengal Florican is a habitat specialist and prefers alluvial grasslands dominated by Imperata cylindrica, Saccharum munja and Desmostachya bipinnata. Bengal Florican is a species with a narrow ecological niche, with a very small and rapidly declining population, largely as a result of the widespread loss of its habitat. (BirdLife International 2001; Rahmani 2001).

On 05 March 2011, during a field visit to Nizam Ghat area near Roing in Lower Dibang Valley District, Arunachal Pradesh at 14:25hr (Image 1), we sighted a male Bengal Florican at New Elopa locality $\left(28^{\circ} 12^{\prime}\right.$ 57.2”N \& 95044'34.9”E) (Image 2). When first sighted, the bird was in flight. Later it settled on the ground, took refuge in the grassland and was out of sight. It was identified with the presence of entirely white wings except for black tips in flight and also with its call (Grimmett et al. 1999). We were able to take a photograph of the bird while in flight which helped us in identifying the bird as male. However, we could not assign the maturity of the individual (adult/subadult) due to inadequate clarity of the image and our limited knowledge on the species.

The breeding season of the species starts from February to July (Ali \& Ripley 1987; Narayan 1992). The mature males establish individual territories in relatively open and short grasslands. Subadult males do not usually establish breeding territories and are seen flying around the breeding sites. However, we cannot conclude anything for the observed behavior from the single sighting.

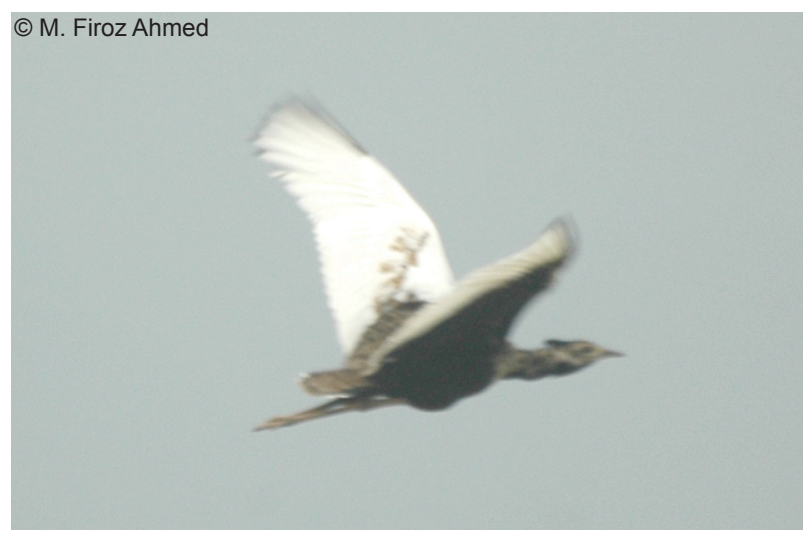

Image 1. Bengal Florican in flight. 


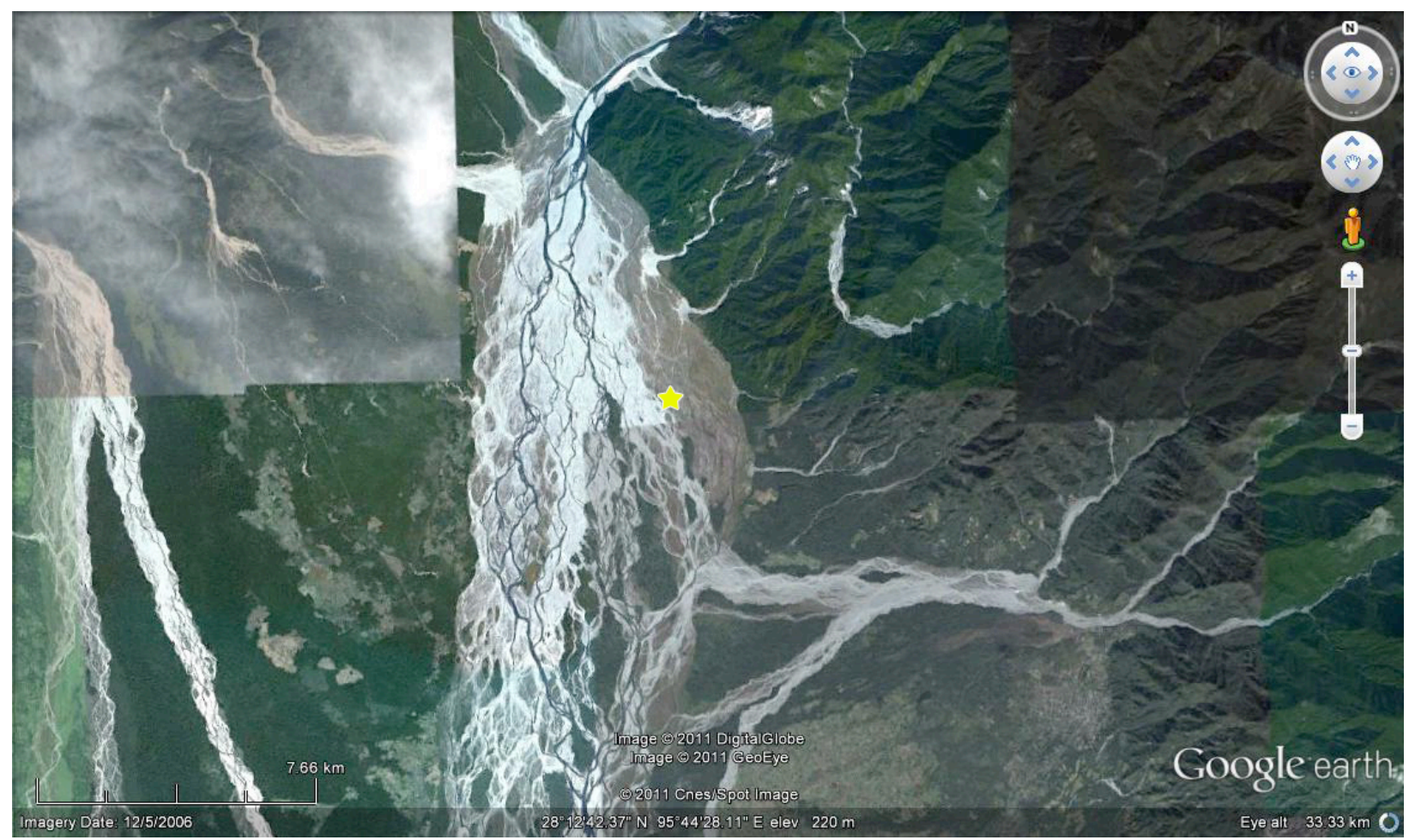

Image 2. Map showing sighting location (solid star) of Bengal Florican in the grassland beside the channels of Dibang River and Nizamghat, Lower Dibang Valley District, Arunachal Pradesh.

We later assessed the habitat that was dominated by the Imperata cylindrica along with other short grasses. The local people also reported sighting of the bird in the area.

Bengal Florican is known to occur in D'Ering Wildlife Sanctuary $\left(27^{0} 51^{\prime}-28^{0} 5^{\prime} \mathrm{N} \& 9^{\circ} 22-95^{\circ} 29^{\prime} \mathrm{E}\right)$ in Arunachal Pradesh (Narayan 1992; Birdlife International 2001). In India population decline due to habitat loss and hunting have restricted the distribution of the species within protected areas only (BirdLife International 2001). However, the species also occurs in some unprotected river islands in eastern India (M. Firoz Ahmed pers. obs. 2003). The significance of this sighting record was that it was outside the protected area in Lower Dibang Valley District in Arunachal Pradesh, which in turn signifies the importance of non protected grasslands in this region.

\section{REFERENCES}

Ali, S. \& S.D. Ripley (1987). Compact Handbook of the Birds of India and Pakistan. Oxford University Press, New Delhi, xlii+737pp+104 colour plates.

BirdLife International (2001). Threatened Birds of Asia - Part $A$. BirdLife International, Cambridge, $\mathrm{xxx}+1516 \mathrm{pp}$.

BirdLife International (2012). Houbaropsis bengalensis. In: IUCN 2012. IUCN Red List of Threatened Species. Version 2012.1. <www.iucnredlist.org>. Downloaded on 16 October 2012.

Grimmett, R., C. Inskipp \& T. Inskipp (1999). Pocket guide to the birds of the Indian subcontinent. Oxford University Press, New Delhi, 384pp.

Poudyal, L.P., P.B. Singh \& S. Maharjan (2008). The decline of Bengal Florican Houbaropsis bengalensis in Nepal. Danphe 17(1): 4-6.

Narayan, G. (1992). Ecology, distribution and conservation of the Bengal Florican Houbaropsis begalensis (Gmelin) in India. PhD Thesis. University of Bombay, IV+301pp.

Rahmani, A.R. (2001). Status of the Bengal Florican Houbaropsis bengalensis in Uttar Pradesh, India. Bombay: Bombay Natural History Society, Bombay. 